\title{
Entrepreneurship in Microscopy: Lessons From a Journey
}

\author{
Thomas F. Kelly ${ }^{1}$
}

${ }^{1 .}$ CAMECA Instruments, Inc., 5470 Nobel Drive, Madison, WI USA

So, maybe you're thinking of starting a company in the microscopy and microanalysis field. You probably would like a roadmap on what to do and when. Well, there is no single way to start a company. There are a myriad of choices and conditions that differ for any given opportunity. However, know that you will almost certainly encounter difficult times and you must have the time, resources and passion to endure through them. Perseverance is your greatest ally.

My experience concerns starting a capital equipment company. Other types of companies like service companies or supplies distributors will have a different set of considerations. There are, nonetheless, some basic questions to consider and answer before taking the plunge.

First and foremost, what is the true market opportunity? What is the market potential that you can exploit? Spend time assessing this question. Can you quantify it? Is it believable to a skeptic? Be honest to yourself because that way you can answer tough questions with confidence. Answers to these questions will underpin everything else you do from your ability to get talented people to join you to raising capital. Sometimes though, you just should trust your intuition on a market opportunity. In the final analysis, listen to your brain but trust your gut.

What is the basis for your winning edge? Performance? Price? Service? Cost of ownership? Novel data? Time to knowledge? What type of innovation are you pursuing? A technological innovation or a business model innovation [1]? You must be addressing a need. However, if you only provide what the market already has, you will not be innovating. You must find some form of differentiation. A new product type? A new-to-the-world device? A major improvement in performance? These are all technical innovations. Or will you provide materials or data or service through a different channel or mode? Is it faster, cheaper, easier? This is business model innovation and it can be every bit as lucrative as technical innovation. Steve Jobs famously said "Innovation is the difference between a leader and a follower." Strive to be a leader.

How can you exploit the opportunity? Are there established players? How will you compete against them? It is easier to break in when there are four players with about equal share rather than one large player with $90 \%$ of the market. They will not give up market share without a fight and bigger players can fight with deeper pockets. More generally, are you competing against a company or a technique.

Cash is the blood on which business runs. One way or another, you must finance a start-up mode. Either you will forego salary (self-financing), you will borrow money (debt financing), or you will sell shares in your venture (equity financing). You may need all three. I did. Consider my example of starting a capital equipment company. To bring in money to fund the business, you must prepare a private offering memorandum. That costs about $\$ 25,000$ in legal fees. This can become a Catch-22 [2]; you must raise money to pay for the legal documents to allow you to raise money. I took out a second mortgage. Then you must write a business plan if you want to raise money. You must either find the time to do the research and write the plan or pay for some help. In my case, I had a day job at the University of Wisconsin and was challenged to find the spare time. The plan was not getting done. I needed to take a 
leave from work, which meant going without salary so I could write the business plan to raise money to pay my salary. This was the second Catch-22. At this point, a savvy investor had faith in me and invested enough to cover my first-year leave. The investor was my mother. So, I wrote the business plan but now that the company was seeking real investment, good business management (not just good engineering) is crucial to raising capital. How could I get the company built up to the point that I could attract top management talent that I needed to raise money so I could hire top business management? Another Catch-22. This time I found another savvy business person: I hired my brother to be President. My point here is that, unless you have $\$ 20 \mathrm{M}$ burning a hole in your pocket, you must find any way you can to raise capital and get things going.

You must be careful with your confidential information. Smart people can figure out what you are doing. They can then patent in your area once they have the idea then they get a patent and you must pay for your own ideas. This happens more often than you might guess.

Remember, time is of the essence. Keep your focus. Consider this: you may be able to make it better but can you afford to sell it later? The first working local electrode atom probe (LEAP) was something only an engineer could love, Fig. 1a. Eventually, there will be time to make it look pretty, Fig. 1b.

Above all, keep on striving. There will be times in your life where you must decide between a risky path with big payback and a safer path. The risky path will not always be the best choice but you should take it sometimes if you want to have real lasting impact. You can't always predict where things will go. Sometimes you just should hang out a shingle announcing your enterprise and let things start to happen. Rarely do things progress according to plan but progress is made nonetheless. It is better to try and fail than never to have tried. Carpe Diem [3].

\section{References:}

[1] T Davila, M Epstein and R Shelton, "Making Innovation Work: How to Manage it, Measure It, and Profit from It" updated edition, Pearson Education, Inc., FT Press, Upper Saddle River, NJ USA (2013). [2] J Heller, "Catch-22" Simon \& Schuster, New York.

[3] The authors acknowledge the team of outstanding men and women who believed in Imago and CAMECA and worked hard to reach our common goal.
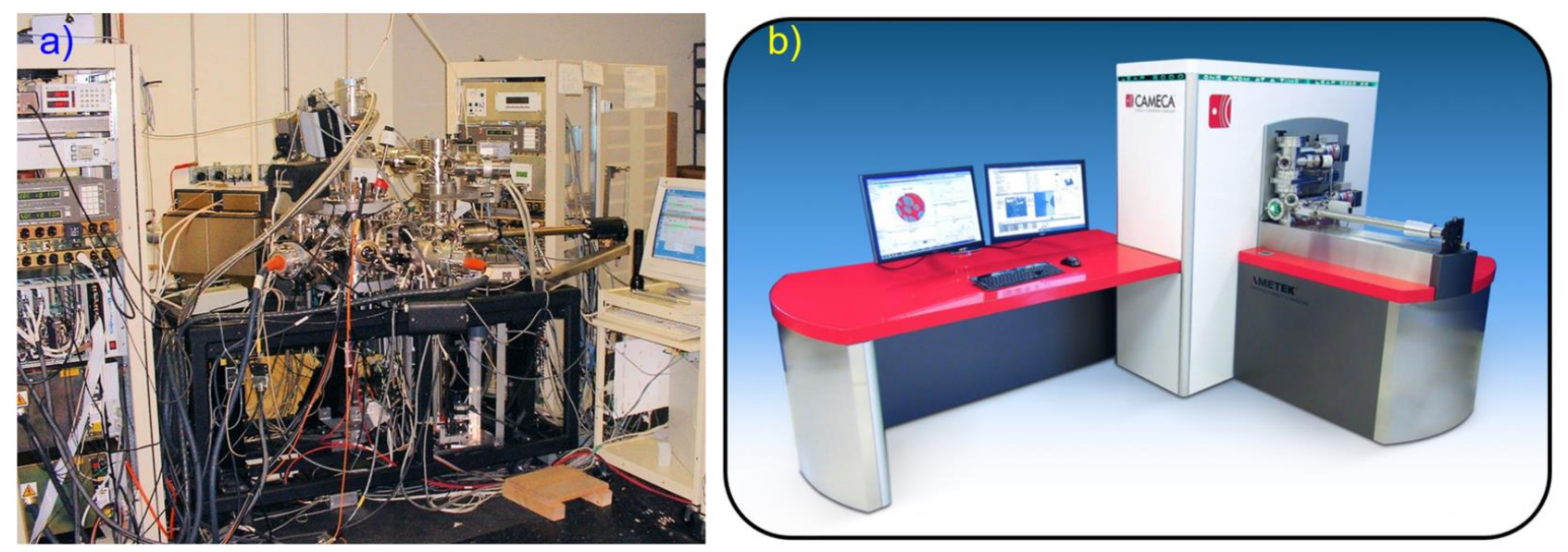

Figure 1. a) Photographs of the first LEAP (alpha prototype) and b) photograph of the current model LEAP 5000. 